Original Research

\title{
Biomass Structure and Morphometric Parameters for Non-Destructive Biomass Estimation of Common Forest Underbrush Species in Lithuania
}

\author{
Mindaugas Škẻma*, Virgilijus Mikšys, Marius Aleinikovas, \\ Benas Šilinskas, Iveta Varnagirytė-Kabašinskienė \\ Institute of Forestry, Lithuanian Research Centre for Agriculture and Forestry, \\ Liepų str. 1, Girionys, LT-53101, Kaunas District, Lithuania
}

Received: 16 March 2017

Accepted: 15 June 2017

\begin{abstract}
A study was conducted to construct functions for aboveground biomass of different components (leaves, stems, and branches) of hazel (Corylus avellana L.), rowan (Sorbus aucuparia L.), and alder buckthorn (Frangula alnus L.) growing naturally under the stand canopy. The functions were designed to calculate the potential amount of biofuel produced from underbrush species in Lithuanian forests. Biomass production of common underbrush species was estimated in seven stands located in in southwestern Lithuania. The ages of the stands varied from 55-70 to 80-100 years. The biomass relationships with morphometric parameters were determined, including stem diameter at $1.3 \mathrm{~m}$ and $0.3 \mathrm{~m}$ above ground level, stem height, and crown length. The study findings showed that biomass relationships for underbrush species were not comparable to the same relationships for canopy trees. As the biomass changes for canopy trees are mostly caused by competition, and the growth of underbrush species depends more on the light regime. Therefore, stem diameter $(\mathrm{D})$ rather than stem height $(\mathrm{H})$ should be better used for estimating total aboveground biomass of underbrush.
\end{abstract}

Keywords: allometric equations, underbrush species, aboveground biomass, stem diameter, stem height

\section{Introduction}

Estimating woody species biomass could be important for carbon sequestration and cycling in forest ecosystems. A common database of forest biomass measurements from Europe would sustain harmonization

*e-mail: skeminis@yahoo.com of carbon accounting methods [1]. For quantifying carbon sequestration, shrub biomass and growth rate have been modelled in different regions [2-3].

Recently, the biomass of canopy trees harvested during thinning and final felling and short rotation forestry for energy purposes is expanding [4]. Furthermore, the biomass derived from underbrush or woody underbrush left after stem harvesting could play an important role for biofuel potential in Lithuania. Underbrush harvest would 
also provide forest owners with additional revenue and could facilitate replanting.

Generally, underbrush is defined as shrubs or small trees growing under the tree canopy. An initial hypothesis of this study could be that allometric development of underbrush species differ from that of canopy trees. However, less attention has been paid to biomass estimates of underbrush compared to canopy trees - especially in mixed forests, where tree competition is more intensive [5-6].

In Lithuanian forest stands, the most common underbrush species are common hazel (Corylus avellana L.), rowan (Sorbus aucuparia L.), and alder buckthorn (Frangula alnus L.). The mentioned species naturally grow as underbrush in deciduous or mixed forests, but individual plants could also be found along riverbanks and in parks, farms, or gardens. The underbrush individuals never reach canopy level in certain conditions. In the forest stands the mean height of rowan and alder buckthorn trees amounts to about $1.2 \mathrm{~m}$, while hazel underbrush is slightly higher and reaches $1.8 \mathrm{~m}$. The average amount of underbrush amounts to 8,600-8,900 stems ha-1 in Lithuanian forests. The main part is registered in deciduous forests, and also in cut areas and forest gaps. The lowest amount is found in coniferous stands [7].

According to the assessment of sustainability, precise estimates of forest biomass could be valued as an essential precondition for forest management [8]. The selection criterion of both model canopy and underbrush trees is one of the most relevant issues for determining different aboveground biomass components (foliage mass, stem, and branches) in different studies [2, 9-14]. Methodologically, more significant data of dry biomass could be obtained when biomass sampling is conducted from the middle until the end of the vegetation period [15].

For evaluating total aboveground tree biomass or biomass of different tree components we used various stem and crown parameters, including stem diameter at breast height (D), height $(\mathrm{H})$, and crown length [1622]. Sometimes, stem volume index $D^{2} \mathrm{H}$ is used [2325]. Several studies show that biomass of canopy trees and their different components (foliage, branches, stem, crown) is relatively closely correlated with morphometric parameters [26-27].

In a study carried out in Botswana, total tree fresh mass of 14 tree species, as a regression between mass and stem basal area at 5-10 cm above ground level, was estimated. A single regression curve was calculated because the curve satisfactorily described the relationship between stem basal area and fresh mass for most trees [28-29]. A strong correlation between hazelnut biomass and stem height and diameter at the stem base was found in Slovenia [30]. According to data obtained in Niepolomice Forest in Poland, species composition of the stand was not the factor mostly affecting underbrush biomass [31].

Earlier findings indicated that the number of small trees and shrubs in underbrush significantly decreases with the increase of stand age [32-33]. The changes of underbrush density and species composition are recorded under the National Forest Inventory. On the other hand, the assessment of forest felling does not include evaluation of underbrush biomass in Lithuania.

Up until now, too little attention has been paid to underbrush biomass assessment and to the peculiarities of the relationship between underbrush biomass and morphometric parameters. This indicates a need to create best-fit parameters for estimating aboveground biomass of underbrush. It is still unclear what parameters best-fit for canopy trees could fit underbrush species. This paper investigates the biomass allocation of hazel (Corylus avellana L.), rowan (Sorbus aucuparia L.), and alder buckthorn (Frangula alnus L.) underbrush, and biomass relationships with morphometric parameters: stem diameter at different heights aboveground, stem height, and the complex index $\mathrm{D}^{2} \mathrm{H}$.

\section{Materials and Methods}

The research site was located in Dubrava Experimental and Training Forest Enterprise (54 $51^{\prime} \mathrm{N}$, $24^{\circ} 03^{\prime}$ E) in southwestern Lithuania. In the study area, the yearly mean temperature is $6.5^{\circ} \mathrm{C}$ and yearly mean precipitation is $686 \mathrm{~mm}$. Six experimental plots were selected in the Norway spruce stands with admixture of deciduous species, and one plot was set up in Scots pine stands. In the experimental sites, the soil type was Luvisol in the Norway spruce stand and Arenosol in the Scots pine stand. The selection scheme for each studied species was designed according to the amount of dominant underbrush.

Fieldwork was conducted in August-September 2009 and 2010. Sample plots of 15 by $20 \mathrm{~m}$ were established for determining morphometric parameters and underbrush stem sampling. Diameters at 0.3 and 1.3 meters above ground level were measured for all stems within the plot (1,684 stems total).

The potential hazel (Corylus avellana L.), rowan (Sorbus aucuparia L.), and alder buckthorn (Frangula alnus L.) underbrush were selected for biomass assessment. No fewer than 30 model underbrush stems were chosen within each plot. Selection of model stems was conducted to encompass the diameter range from each plot, i.e., taking the stems from the lowest to highest diameter groups within each plot. The procedure was applied following the idea that measuring a higher number of stems in the plot does not give higher data accuracy and does not compensate for the time-input [34-35]. The model stems were cut down at $0.1 \mathrm{~m}$ distance from the stem base.

The following morphometric parameters were measured: stem height, stem diameter at 0.3 and $1.3 \mathrm{~m}$ heights, and crown length. The fresh biomass of different components (branches, stems, and leaves) was assessed. In total, 92 hazel stems and 63 stems each for rowan 
Table 1. Main characteristics of sampled plots.

\begin{tabular}{|c|c|c|c|c|c|}
\hline $\begin{array}{l}\text { Plot } \\
\text { No. }\end{array}$ & Undergrowth species & $\begin{array}{c}\text { Species } \\
\text { composition* }\end{array}$ & $\begin{array}{l}\text { Stand age } \\
\text { (years) }\end{array}$ & $\begin{array}{c}\text { Stocking } \\
\text { level }\end{array}$ & $\begin{array}{c}\text { Forest } \\
\text { site }\end{array}$ \\
\hline 1 & \multirow{3}{*}{ Hazel (Corylus avellana L.) } & 8E1Ą1B & 107 & 0.9 & $\mathrm{Nc}$ \\
\hline 2 & & 6E2Ą2B & 82 & 0.8 & $\mathrm{Nc}$ \\
\hline 3 & & 5Ą4E1P & 92 & 0.7 & $\mathrm{Nc}$ \\
\hline 4 & \multirow{2}{*}{ Rowan (Sorbus aucuparia L.) } & 8E1Ą1B & 100 & 0.9 & $\mathrm{Nc}$ \\
\hline 5 & & 7E3B & 90 & 0.8 & Lc \\
\hline 6 & \multirow{2}{*}{ Alder buckthorn (Frangula alnus L.) } & $10 \mathrm{P}$ & 70 & 0.7 & Lc \\
\hline 7 & & 5E2B2J1D & 55 & 0.8 & Lc \\
\hline
\end{tabular}

*E - Picea abies (L.) H. Karst., A - Quercus robur L., B - Betula pubescens Ehrh., P - Pinus sylvestris L., J - Alnus glutinosa (L.) Gaertn., D - Populus tremula L.

** $\mathrm{Nc}$ - mineral mesoeutrophic soils of normal moisture, Lc - mesoeutrophic temporary overmoistured soils

and buckthorn were measured. The main characteristics of the sampled underbrush are given in Table 1.

The moisture content of underbrush biomass was first estimated. The branches were removed from the stems, all leaves were removed from the branches, and these components were weighed separately. Stem, branch, and foliage samples of $0.5 \mathrm{~kg}$ were taken, weighed, and put into clean paper bags. The samples were dried at $105^{\circ} \mathrm{C}$ for 24 hours until constant weight for determining dry biomass and the dried samples were weighed. Under the same environmental conditions, the average moisture of stems amounted to about $45-48 \%$ for hazel, rowan, and buckhorn (data not shown). Higher moisture contents of $52-53 \%$ and $63-64 \%$ were found for the branches and leaves, respectively.

To evaluate the relationship between underbrush biomass components and morphometric parameters and to construct the functions for underbrush biomass evaluation, we tested a non-linear regression model using $\mathrm{D}, \mathrm{H}$, and $\mathrm{D}^{2} \mathrm{H}$, and together $\mathrm{D}$ and $\mathrm{H}$ as independent variables. The following function was applied:

$$
\mathrm{Y}=\mathrm{a} 0 \times \mathrm{P} 1^{\mathrm{a} 1} \times \mathrm{P} 2^{\mathrm{a} 2} \times \ldots,
$$

...where $\mathrm{Y}$ is biomass component (leaf biomass, branches biomass, etc.); a0, a1, a2, etc. are coefficients; and P1, P2, etc. are stem parameters $\left(\mathrm{D}, \mathrm{H}, \mathrm{D}^{2} \mathrm{H}\right)$.

The coefficient of determination $\left(\mathrm{R}^{2}\right)$ was used to evaluate the fitness of the models. The best models were then used on biomass data from the sample stems to present equations describing the relationship between the biomass components and morphometric parameters $\mathrm{D}$ and $\mathrm{H}$.

A regression analyses was used for the statistical relationship between different variables. Statistical analyses were conducted using the software Statistica 7.0, and a level of significance of $\alpha=0.05$ was chosen in all cases.

\section{Results and Discussion}

Various biomass distribution models, as a good tool for improving the pre-harvest estimates of harvested volume, could also be important for the underbrush species [37]. When the underbrush study was conducted, the results showed that stem biomass made the biggest relative contribution to total aboveground biomass, amounting to 68,73 , and $66 \%$ for the underbrush hazel (Corylus avellana L.), rowan (Sorbus aucuparia L.), and alder buckthorn (Frangula alnus L.) stems, respectively (Table 2). Differences of the relative contribution were not significant among different underbrush species $(P>0.05)$.

A number of studies demonstrated that hazel leaf biomass amounted from $10-12 \%$ [32] to about $17 \%$ [30] from total aboveground biomass. The data of hazel stem biomass were comparable to a study carried out in the northern United States, where stems comprised 49-55\% from total aboveground biomass [30].

Relatively similar biomass contributions of various components were obtained for canopy trees. Both for deciduous and coniferous tree species, mean stem biomass accounted for $75-80 \%$ from total aboveground biomass, foliage biomass amounted to about $4-8 \%$, living branches to $14-20 \%$, and dead branches to less than $3 \%$ [38]. The study also indicated that stem-to-foliage mass ratio ranged from 1.93 (alder buckthorn) to 2.69 (rowan),

Table 2. Mean dry biomass of different components of the various undergrowth species $\pm \mathrm{SE}$, percent from total aboveground biomass.

\begin{tabular}{|c|c|c|c|}
\hline \multirow{2}{*}{$\begin{array}{c}\text { Biomass } \\
\text { component }\end{array}$} & $\begin{array}{c}\text { Corylus } \\
\text { avellana } \mathrm{L} .\end{array}$ & $\begin{array}{c}\text { Sorbus } \\
\text { aucuparia } \mathrm{L} .\end{array}$ & $\begin{array}{c}\text { Frangula } \\
\text { alnus L. }\end{array}$ \\
\cline { 2 - 4 } & \multicolumn{3}{|c|}{$\begin{array}{c}|c| \\
\text { Mean dry biomass, percent from total aboveg- } \\
\text { round biomass }\end{array}$} \\
\hline Stem & $68.2 \pm 2.1$ & $72.9 \pm 2.9$ & $65.9 \pm 2.8$ \\
\hline Branches & $20.5 \pm 1.2$ & $18.9 \pm 1.5$ & $24.5 \pm 1.4$ \\
\hline Leaves & $11.3 \pm 0.8$ & $8.2 \pm 1.0$ & $9.6 \pm 0.9$ \\
\hline
\end{tabular}




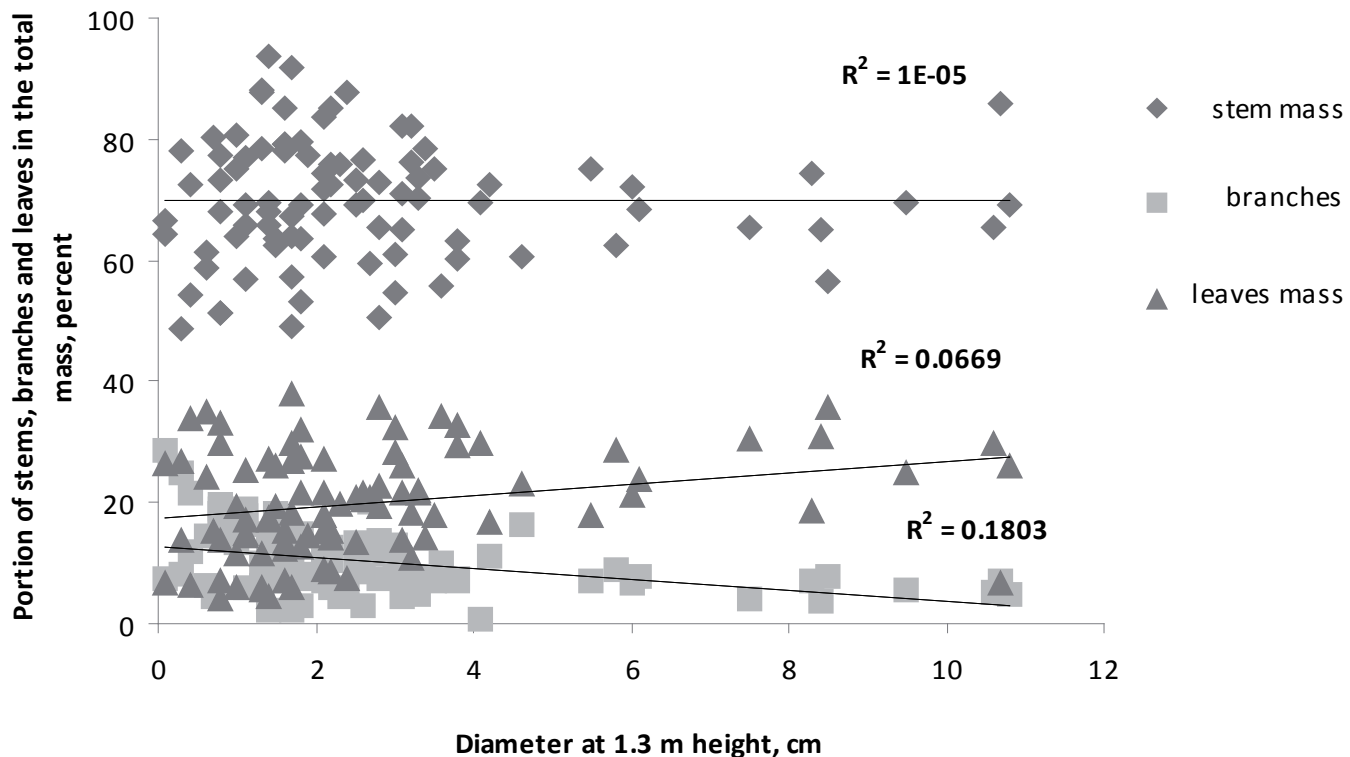

Fig. 1. Dependence of the portion of hazel stems, branches, and leaves on diameter at $1.3 \mathrm{~m}$ height.

but mean values of the ratio did not differ significantly among different underbrush species.

The results obtained from this study showed that the portions of stems, branches, and leaves in total underbrush stem biomass did not significantly depend on morphometric parameters. Analyzing the data of hazel underbrush components, regression analysis of biomass percentage of components with stem diameter at $1.3 \mathrm{~m}$ height was performed (Fig. 1). There was no relationship between stem diameter and the biomass portion of stems, branches, and leaves. The portion of hazel and rowan branches increased insignificantly with increasing diameter, while that of leaves decreased. The portion of both leaves and branches of buckthorn remained stable with increasing diameter (data not shown).

These results differ from the results obtained from aboveground biomass studies of canopy trees. For the canopy trees, with increasing tree age and morphometric parameters, biomass is mostly accumulated in the stems of trees; thus the stem biomass of older and larger trees as well as of older stands is considerably greater than that of young trees and stands [38]. However, these peculiarities are not characteristic for the biomass of underbrush species, i.e., hazels, rowans, and buckthorns. This result may be explained by the fact that underbrush species grow under limited light, i.e., the amount of light is a more limiting factor than competition among the individuals. Such conditions almost eliminate gradual self-cleaning from branches, and all components of underbrush develop more proportionally.

Prediction equations are used worldwide to estimate the amount of biomass at the tree, stand, and landscape levels. The resulting non-linear regression functions for total aboveground biomass of underbrush, as a function of tree dimensional parameters $\mathrm{D}_{1.3}$ and $\mathrm{D}_{1.3}{ }^{2} \mathrm{H}$, showed $\mathrm{R}^{2}$ values ranging from 0.932 to $0.987(\mathrm{p} \leq 0.001$ for rowan and alder buckthorn, $\mathrm{p} \leq 0.03$ for hazel; Table 3 ).
Relatively high coefficients of determination were ascertained between the total mass of hazel, rowan, and buckthorn underbrush and stem diameters at $0.3 \mathrm{~m}$ height: $\mathrm{R}^{2}$ values ranged between 0.912 and $0.988(\mathrm{p} \leq 0.001$ for rowan and buckthorn, $\mathrm{p} \leq 0.04$ for hazel; Table 3). The parameter $\mathrm{D}_{0.3}$ was tested to check whether more accurate shrub stem diameter values would increase the reliability of indicators. However, our findings confirmed that despite slightly higher $\mathrm{R}^{2}$ values obtained for $\mathrm{D}_{0.3}$, no significant differences from $\mathrm{D}_{1.3}$ were determined.

In the case of hazel, the most appropriate predictable parameters were $\mathrm{D}_{1.3}$ and $\mathrm{D}_{1.3}{ }^{2} \mathrm{H}$ both for stems and crown biomass components (branches and leaves), giving $\mathrm{R}^{2}$ values of $0.973,0.786-0.800$, and $0.926-0.931$, respectively (Table 4).

The parameters $\mathrm{D}$ and $\mathrm{D}_{1.3}{ }^{2} \mathrm{H}$ were the best predictors for estimating total aboveground and stem biomass of rowan, giving $\mathrm{R}^{2}$ values ranging from 0.96 to 0.99 ( $p=0.001$; data not shown). The $\mathrm{R}^{2}$ values were to some extent lower, ranging from 0.88 to 0.95 , for estimations of leaf and branch biomass.

Compared to hazel and rowan, similar results were obtained for alder buckthorn biomass estimations. The coefficients of determination were highest for the equations with $\mathrm{D}\left(\mathrm{R}^{2}\right.$ was $\left.0.93-0.98\right)$ and $\mathrm{D}^{2} \mathrm{H}\left(\mathrm{R}^{2}\right.$ was close to 0.99). It was a proper parameter for the stem biomass evaluation (data not shown).

For all studied underbrush species, the relationships as a function of height $(\mathrm{H})$ showed lower coefficient of determination, ranging from 0.597 to 0.973 , compared with the relationships as a function of other independent variables. The equations for branch and leaf biomass had a weaker relationship than those for stem biomass.

Comparable results were obtained when the biomass of canopy trees was studied. Mikšys et al. [38] found a weaker relationship of tree height or crown parameters to tree biomass compared to stem diameter. Subsequently, the 
Table 3. Relationships of total biomass of hazel, rowan, and Alder buckthorn to their morphometric parameters.

\begin{tabular}{|c|c|c|c|c|c|c|}
\hline Morphometric parameters* & Coefficient of determination $\left(\mathrm{R}^{2}\right)$ & Coefficient & Estimate & Standard error & $t$-value & $p$-level \\
\hline \multicolumn{7}{|c|}{ Hazel Corylus avellana L. } \\
\hline \multirow{2}{*}{$\mathrm{H}$} & \multirow{2}{*}{0.783} & a & 0.002 & 0.002 & 1.276 & 0.205 \\
\hline & & $\mathrm{b}$ & 3.940 & 0.331 & 11.898 & 0.000 \\
\hline \multirow{2}{*}{$\mathrm{D}_{1.3}$} & \multirow{2}{*}{0.938} & a & 0.068 & 0.022 & 3.099 & 0.002 \\
\hline & & $\mathrm{b}$ & 2.745 & 0.141 & 19.414 & 0.000 \\
\hline \multirow{2}{*}{$\left(\mathrm{D}_{1.3}\right)^{2} \times \mathrm{H}$} & \multirow{2}{*}{0.932} & $\mathrm{a}$ & 0.012 & 0.005 & 2.170 & 0.032 \\
\hline & & $\mathrm{b}$ & 1.144 & 0.066 & 17.234 & 0.000 \\
\hline \multirow{3}{*}{$\mathrm{D}_{1.3}$ and $\mathrm{H}$} & \multirow{3}{*}{0.938} & $\mathrm{a}$ & 0.054 & 0.034 & 1.580 & 0.117 \\
\hline & & $\mathrm{b}$ & 2.694 & 0.198 & 13.605 & 0.000 \\
\hline & & $\mathrm{c}$ & 0.147 & 0.361 & 0.409 & 0.683 \\
\hline \multirow{2}{*}{$\mathrm{D}_{0.3}$} & \multirow{2}{*}{0.912} & $\mathrm{a}$ & 0.031 & 0.015 & 2.112 & 0.037 \\
\hline & & $\mathrm{b}$ & 2.931 & 0.197 & 14.815 & 0.000 \\
\hline \multicolumn{7}{|c|}{ Rowan Sorbus aucuparia L. } \\
\hline \multirow{2}{*}{$\mathrm{H}$} & \multirow{2}{*}{0.910} & a & 0.001 & 0.001 & 1.671 & 0.099 \\
\hline & & $\mathrm{b}$ & 5.123 & 0.412 & 12.411 & 0.001 \\
\hline \multirow{2}{*}{$\mathrm{D}_{1.3}$} & \multirow{2}{*}{0.969} & a & 0.164 & 0.014 & 11.196 & 0.001 \\
\hline & & $\mathrm{b}$ & 2.047 & 0.081 & 25.102 & 0.001 \\
\hline \multirow{2}{*}{$\left(\mathrm{D}_{1.3}\right)^{2} \times \mathrm{H}$} & \multirow{2}{*}{0.975} & $\mathrm{a}$ & 0.063 & 0.007 & 8.484 & 0.001 \\
\hline & & $\mathrm{b}$ & 0.882 & 0.032 & 26.981 & 0.001 \\
\hline \multirow{3}{*}{$\mathrm{D}_{1.3}$ and $\mathrm{H}$} & \multirow{3}{*}{0.975} & a & 0.042 & 0.014 & 2.871 & 0.005 \\
\hline & & $\mathrm{b}$ & 1.646 & 0.123 & 13.318 & 0.001 \\
\hline & & $\mathrm{c}$ & 1.237 & 0.305 & 4.041 & 0.001 \\
\hline \multirow{2}{*}{$\mathrm{D}_{0.3}$} & \multirow{2}{*}{0.988} & $\mathrm{a}$ & 0.070 & 0.004 & 14.200 & 0.001 \\
\hline & & $\mathrm{b}$ & 2.303 & 0.052 & 44.087 & 0.001 \\
\hline \multicolumn{7}{|c|}{ Alder buckthorn Frangula alnus L. } \\
\hline \multirow{2}{*}{$\mathrm{H}$} & \multirow{2}{*}{0.742} & $\mathrm{a}$ & 0.012 & 0.010 & 1.166 & 0.247 \\
\hline & & $\mathrm{b}$ & 3.166 & 0.540 & 5.863 & 0.000 \\
\hline \multirow{2}{*}{$\mathrm{D}_{1.3}$} & \multirow{2}{*}{0.982} & $\mathrm{a}$ & 0.121 & 0.011 & 10.975 & 0.000 \\
\hline & & $\mathrm{b}$ & 2.480 & 0.065 & 38.088 & 0.000 \\
\hline & & $\mathrm{a}$ & 0.022 & 0.003 & 7.265 & 0.000 \\
\hline$\left(D_{1.3}\right) \times n$ & 0.981 & $\mathrm{~b}$ & 1.183 & 0.031 & 37.517 & 0.000 \\
\hline & & $\mathrm{a}$ & 0.043 & 0.012 & 3.606 & 0.000 \\
\hline $\mathrm{D}_{1.3}$ and $\mathrm{H}$ & 0.988 & $\mathrm{~b}$ & 2.408 & 0.062 & 38.323 & 0.000 \\
\hline & & $\mathrm{c}$ & 0.717 & 0.179 & 3.993 & 0.000 \\
\hline & & $\mathrm{a}$ & 0.123 & 0.010 & 11.830 & 0.000 \\
\hline $\mathbf{D}_{0.3}$ & 0.905 & $\mathrm{~b}$ & 2.067 & 0.050 & 41.246 & 0.000 \\
\hline
\end{tabular}

*Note: $H$-stem height, $m ; D_{1.3}-$ stem diameter at $1.3 \mathrm{~m}$ height $\mathrm{cm} ; D_{0.3}-$ stem diameter at $0.3 \mathrm{~m}$ height, $\mathrm{cm} ;\left(D_{1.3}\right)^{2} x H-s q u a r e$ stem diameter at $1.3 \mathrm{~m}$ height and stem height; $D_{1,3}$ and $H$-stem diameter at $1.3 \mathrm{~m}$ height and stem height. 
data showed that there was no reasonable explanation for the use of both diameter (D) and height $(\mathrm{H})$ because height parameter did not change the reliability of the equations. There are a number of important differences between the aboveground biomass assessment of underbrush and canopy trees. For example, stem diameter (D), height $(\mathrm{H})$, and $\mathrm{D}^{2} \mathrm{H}$ index are often used for the canopy trees stem biomass functions, but they are less informative for estimating crown and leaf or needle biomass [38-39]. In general, when changes in stem diameter, stand age, or

Table 4. Relationships of different biomass components of hazel (Corylus avellana L.) to their morphometric parameters.

\begin{tabular}{|c|c|c|c|c|c|c|c|}
\hline & Morphometric parameters* & $\begin{array}{c}\text { Coefficient of } \\
\text { determination }\left(\mathrm{R}^{2}\right)\end{array}$ & $\begin{array}{l}\text { Coeffi- } \\
\text { cient }\end{array}$ & Estimate & Standard error & $t$-value & $p$-level \\
\hline \multirow{11}{*}{ Leaves } & \multirow{2}{*}{$\mathrm{H}$} & \multirow{2}{*}{0.821} & $\mathrm{a}$ & 0.0001 & 0.000 & 1.751 & 0.083 \\
\hline & & & $\mathrm{b}$ & 3.491 & 0.243 & 14.322 & 0.000 \\
\hline & \multirow{2}{*}{$\mathrm{D}_{1.3}$} & \multirow{2}{*}{0.931} & a & 0.017 & 0.003 & 4.973 & 0.000 \\
\hline & & & $\mathrm{b}$ & 2.038 & 0.090 & 22.518 & 0.000 \\
\hline & \multirow{2}{*}{$\mathrm{D}_{0.3}$} & \multirow{2}{*}{0.903} & a & 0.012 & 0.003 & 3.858 & 0.000 \\
\hline & & & $\mathrm{b}$ & 2.073 & 0.111 & 18.643 & 0.000 \\
\hline & \multirow{2}{*}{$\left(D_{1.3}\right)^{2} \times H$} & \multirow{2}{*}{0.926} & a & 0.006 & 0.001 & 3.748 & 0.000 \\
\hline & & & $\mathrm{b}$ & 0.825 & 0.039 & 20.955 & 0.000 \\
\hline & \multirow{3}{*}{$\mathrm{D}_{1.3}$ and $\mathrm{H}$} & \multirow{3}{*}{0.931} & a & 0.018 & 0.008 & 2.114 & 0.037 \\
\hline & & & $\mathrm{b}$ & 2.051 & 0.183 & 11.201 & 0.000 \\
\hline & & & $\mathrm{c}$ & -0.028 & 0.334 & -0.083 & 0.933 \\
\hline \multirow{11}{*}{ Branches } & \multirow{2}{*}{$\mathrm{H}$} & \multirow{2}{*}{0.597} & $\mathrm{a}$ & 0.0006 & 0.000 & 0.796 & 0.427 \\
\hline & & & $\mathrm{b}$ & 4.010 & 0.532 & 7.527 & 0.000 \\
\hline & \multirow{2}{*}{$\mathrm{D}_{1.3}$} & \multirow{2}{*}{0.800} & $\mathrm{a}$ & 0.003 & 0.003 & 1.096 & 0.275 \\
\hline & & & $\mathrm{b}$ & 3.506 & 0.392 & 8.934 & 0.000 \\
\hline & \multirow{2}{*}{$\mathrm{D}_{0.3}$} & \multirow{2}{*}{0.778} & $\mathrm{a}$ & 0.0004 & 0.000 & 0.699 & 0.485 \\
\hline & & & $\mathrm{b}$ & 4.193 & 0.584 & 7.170 & 0.000 \\
\hline & \multirow{2}{*}{$\left(\mathrm{D}_{1.3}\right)^{2} \mathrm{xH}$} & \multirow{2}{*}{0.786} & $\mathrm{a}$ & 0.0002 & 0.000 & 0.720 & 0.473 \\
\hline & & & $\mathrm{b}$ & 1.539 & 0.197 & 7.785 & 0.000 \\
\hline & \multirow{3}{*}{$\mathrm{D}_{1.3}$ and $\mathrm{H}$} & \multirow{3}{*}{0.800} & $\mathrm{a}$ & 0.007 & 0.011 & 0.621 & 0.535 \\
\hline & & & $\mathrm{b}$ & 3.547 & 0.443 & 8.007 & 0.000 \\
\hline & & & $\mathrm{c}$ & -0.296 & 0.789 & -0.375 & 0.708 \\
\hline \multirow{11}{*}{ Stem } & \multirow{2}{*}{$\mathrm{H}$} & \multirow{2}{*}{0.973} & $\mathrm{a}$ & 0.001 & 0.001 & 1.600 & 0.113 \\
\hline & & & $\mathrm{b}$ & 3.940 & 0.264 & 14.873 & 0.000 \\
\hline & \multirow{2}{*}{$\mathrm{D}_{1.3}$} & \multirow{2}{*}{0.973} & $\mathrm{a}$ & 0.065 & 0.012 & 5.420 & 0.000 \\
\hline & & & $\mathrm{b}$ & 2.563 & 0.081 & 31.535 & 0.000 \\
\hline & \multirow{2}{*}{$\mathrm{D}_{0.3}$} & $0 \Omega$ & $\mathrm{a}$ & 0.034 & 0.010 & 3.263 & 0.001 \\
\hline & & 0.949 & $\mathrm{~b}$ & 2.705 & 0.128 & 21.020 & 0.000 \\
\hline & & 0.07 & a & 0.014 & 0.003 & 4.031 & 0.000 \\
\hline & $\left(D_{1.3}\right) \times \Pi$ & 0.915 & $\mathrm{~b}$ & 1.060 & 0.035 & 29.506 & 0.000 \\
\hline & & & $\mathrm{a}$ & 0.029 & 0.010 & 2.723 & 0.007 \\
\hline & $\mathrm{D}_{1.3}$ and $\mathrm{H}$ & 0.975 & $\mathrm{~b}$ & 2.353 & 0.117 & 19.979 & 0.000 \\
\hline & & & $\mathrm{c}$ & 0.534 & 0.215 & 2.486 & 0.014 \\
\hline
\end{tabular}

*Note: $H$-stem height, $m ; D_{1.3}-$ stem diameter at $1.3 \mathrm{~m}$ height $\mathrm{cm} ; D_{0.3}-$ stem diameter at $0.3 \mathrm{~m}$ height, $\mathrm{cm} ;\left(D_{1.3}\right)^{2} x H-$ square stem diameter at $1.3 \mathrm{~m}$ height and stem height; $D_{1,3}$ and $H$-stem diameter at $1.3 \mathrm{~m}$ height and stem height. 
density occur, the values of crown biomass should vary considerably. For canopy trees with the same diameter, crown biomass portion decreases with increasing stand age [38].

Underbrush species grow under limited light conditions (under tree canopy layer), which could explain why their biomass relationships are not comparable to the same relationships for canopy trees. When discussing canopy trees, biomass changes are mostly caused by competition. However, the growth of underbrush species depends more on light regime than on competition [4041]. Therefore, stem diameter (D) rather than stem height (H) would be better used for estimating total aboveground underbrush biomass. The underbrush stem diameter does not much relate to the growth restrictions compared to underbrush height.

We also tested equations in which crown length was included as an independent variable. In this case, $R^{2}$ values were less than 0.45 for buckthorn, and less than 0.85 each for hazel and rowan ( $p<0.05$, data not shown).

The obtained theoretical implications of the certain link to practical applications still remain under discussion, since the available data of underbrush species from the Lithuanian National Forest Inventory mainly include underbrush height measurements. As this could be a limitation of using these equations, however, they could be used in practice when underbrush biomass resources should be evaluated in individual stands, as stem diameter measurements are less demanding than height measurements. The obtained equations are basically important for scientific studies, which require accurate underbrush biomass determination. This is also an important issue for future studies based on estimating carbon stocks stored in the underbrush.

\section{Conclusions}

In this study, we presented a set of biomass equations for the common underbrush species hazel (Corylus avellana L.), rowan (Sorbus aucuparia L.), and alder buckthorn (Frangula alnus L.) in Lithuania. The results showed that biomass allocation (portions of stems, leaves, and branches) of hazel, rowan, and buckthorn remained stable throughout the range of sizes for the species. This structure differs from that obtained for the canopy trees, which is characterized by the stem biomass portion increase with tree size.

The highest $\mathrm{R}^{2}$ values were ascertained between total aboveground biomass and different underbrush components (stems, branches, leaves, and crown) with their stem diameters at 0.3 and $1.3 \mathrm{~m}$ heights $\left(\mathrm{R}^{2}\right.$ 0.77-0.98). Using the complex indicator $\mathrm{D}^{2} \mathrm{H}$ instead of stem diameter, $\mathrm{R}^{2}$ values changed insignificantly.

When two independent variables (stem diameter and height) were used to assess underbrush biomass of hazels, rowans, and buckthorns, $\mathrm{R}^{2}$ values also changed insignificantly. These findings may help us understand that the regularities of biomass changes for underbrush species are not comparable to the same relationships for canopy trees because the growth of underbrush species is more limited by light regime under the canopy than the competition.

\section{Acknowledgements}

The research presented in this paper was from a longterm research program, "Sustainable forestry and global changes," implemented by the Lithuanian Research Centre for Agriculture and Forestry.

\section{References}

1. LANG M., LILLELEHT A., NEUMANN M., BRONISZ K., ROLIM S.G., SEEDRE M., URI V., KIVISTE A. Estimation of above-ground biomass in forest stands from regression on their basal area and height. Forestry Studies / Metsanduslikud Uurimused. 64, 70, 2016.

2. PASALODOS-TATO M., RUIZ-PEINADO R., DEL RÍO M., MONTERO G. Shrub biomass accumulation and growth rate models to quantify carbon stocks and fluxes for the Mediterranean region. Eur J For Res. 134 (3), 537, 2015.

3. ALÍAS J.C., GARCÍA M., SOSA T., VALARES C., CHAVES N. Carbon storage in the different compartments of two systems of shrubs of the southwestern Iberian Peninsula. Agroforest Syst. 89 (4), 575, 2015.

4. RYTTER L., INGERSLEV M., KILPELÄINEN A., TORSSONEN P., LAZDINA D., LÖF M., MADSEN P., MUISTE P., STENER L.-G. Increased forest biomass production in the Nordic and Baltic countries - a review on current and future opportunities. Silva Fenn. 50 (5), article id 1660, 2016.

5. LIMAA., SUWA R., DEMELLORIBEIROG., KAJIMOTO T., DOS SANTOS J., DA SILVA R.P., DE SOUZA C.A.S., DE BARROS P.C., NOGUCHI H., ISHIZUKA M., HIGUCHI N.: Allometric models for estimating above- and below-ground biomass in Amazonian forests at São Gabriel da Cachoeira in the upper Rio Negro, Brazil, Forest Ecol. Manag. 277, 163, 2012.

6. WANG J., FAN J., FAN X., ZHANG C., WU L., V. GADOW $\mathrm{K}$. Crown and root biomass equations for the small trees of Pinus koraiensis under canopy. Dendrobiol. 70, 13, 2013.

7. KULIEŠIS A., KULBOKAS G. Lithuanian forest inventory 2004-2008. Forest resources and their dynamic. Statistics of Lithuanian Forests, Part 2; Publisher: Ministry of Environment, State Forest Service, Kaunas: Lutute, Lithuania, 2009 [In Lithuanian].

8. ALBERT K., ANNIGHÖFER P., SCHUMACHER J., AMMER C. Biomass equations for seven different tree species growing in coppice-with-standards forests in Central Germany. Scand J Forest Res. 29 (3), 210, 2014.

9. DE-MIGUEL S., PUKKALA T., ASSAF N., SHATER Z. Intra-specific differences in allometric equations for aboveground biomass of eastern Mediterranean Pinus brutia. Ann. For. Sci. 71, 101, 2014.

10. GOODMAN R.C., PHILLIPS O.L., TORRES D.C., FREITAS L., CORTESE S.T., MONTEAGUDO A., BAKER T.R. Amazon palm biomass and allometry. Forest Ecol Manag. 310, 994, 2013. 
11. JAGODZIŃSKI A.M., KAŁUCKA I., HORODECKI P., OLEKSYN J. Aboveground biomass allocation and accumulation in a chronosequence of young Pinus sylvestris stands growing on a lignite mine spoil heap. Dendrobiol. 72, 139, 2014.

12. QUINT T.C., DECH J.P. Allometric models for predicting the aboveground biomass of Canada yew (Taxus canadensis Marsh.) from visual and digital cover estimates. Can. J. For. Res. 40, 2003, 2010.

13. ZENG W.S., TANG S.Z., HUANG G.S., ZHANG M. Population classification and sample structure on modeling of single-tree biomass equations for national biomass estimation in China. For. Resour. Manag. 3, 16, 2010.

14. ZIANIS D., XANTHOPOULOS G., KALABOKIDIS K., KAZAKIS G., GHOSN D., ROUSSOU O. Allometric equations for aboveground biomass estimation by size class for Pinus brutia Ten. trees growing in Northand South Aegean Islands, Greece. Eur. J. For. Res. 130, 145, 2011.

15. SUSTANOVA O.V. [СУСТАВOBA O.B.] Structure and dynamics of artificial origin pine stands in the conditions of the steppe Zauralye [Структура и динамика сосновых древостоев искусственного происхождения в условиях степного Зауралья] Dissertation of Agricultural Sciences: 06.03.02: Ekaterinburg, 217 pp. RSL OD, 61:05-6/237, 2004 [In Russian].

16. BASUKI T.M., van LAAKE P.E., SKIDMORE A.K., HUSSIN Y.A. Allometric equations for estimating the above-ground biomass in tropical lowland Dipterocarp forests. Forest Ecol Manag. 257, 1684, 2009.

17. CRECENTE-CAMPO F., MARSHALL P., LEMAY V., DIEGUEZ -ARANDA U. A crown profile model for Pinus radiate D. Don in northwestern Spain. Forest Ecol Manag. 257, 2370, 2009.

18. DIBDIAKOVA J. Branch biomass of Norway spruce as a potential raw material in some geographical locations in Southern Norway. 20 $0^{\text {th }}$ European Biomass Conference and Exhibition, 18-22 June, Milan, Italy, 2012.

19. FELDPAUSCH T.R., BANIN L., PHILLIPS O.L., BAKER T.R., LEWIS S.L., QUESADA C.A., AFFUM-BAFFOE K., ARETS E.J.M.M., BERRY N.J., BIRD M., BRONDIZIO E.S., DE CAMARGO P., CHAVE J., DJAGBLETEY G., DOMINGUES T.F., DRESCHER M., FEARNSIDE P.M., M. B. FRANÇA, FYLLAS N.M., LOPEZ-GONZALEZ G., HLADIK A., HIGUCHI N., HUNTER M.O., IIDA Y., SALIM K.A., KASSIM A.R., KELLER M., KEMP J., KING D.A., LOVETT J.C., MARIMON B.S., MARIMONJUNIOR B.H., LENZA E., MARSHALL A.R., METCALFE D. J., MITCHARD E.T.A., MORAN E.F., NELSON B.W., NILUS R., NOGUEIRA E.M., PALACEL M., PATIÑO S., PEH K.S.-H., RAVENTOS M.T., REITSMA J.M., SAIZ G., SCHRODT F., SONKE B., TAEDOUMG H.E., TAN S., WHITE L., WOLL H., LLOYD J. Height-diameter allometry of tropical forest trees. Biogeosciences. 8, 1081, 2011.

20. HUNTER M.O., KELLER M., VICTORIA D., MORTON D.C. Tree height and tropical forest biomass estimation. Biogeosciences. 10, 8385, 2013.

21. JELONEK T., PAZDROWSKI W., WALKOWIAK R., ARASIMOWICZ-JELONEK M., TOMCZAK A. Allometric models of foliage biomass in Scots pine (Pinus sylvestris L.). PJoES. 20 (2), 355, 2011.

22. REPOLA J. Biomass equations for Scots pine and Norway spruce in Finland. Silva Fenn. 43 (4), 625, 2009.
23. GOODMAN R.C., PHILLIPS O.L., BAKER T.R. The importance of crown dimensions to improve tropical tree biomass estimates. Ecol. Appl. 24, 680, 2014.

24. HOSODA K., IEHARA T. Aboveground biomass equations for individual trees of Cryptomeria japonica, Chamaecyparis obtusa and Larix kaempferi in Japan. J For Res. 15, 299, 2010.

25. ZOU W.-T., ZENG W.-S., ZHANG L.-J., ZENG M. Modelling Crown Biomass for Four Pine Species in China. Forests. 6, 433, 2015

26. KHOSRAVI S., NAMIRANIAN M., GHAZANFARI H., SHIRVANI A. Crown biomass relationships of Lebanon oak in northern Zagros forests of Iran. Croat. J. For. Eng. 33, 239, 2012

27. POORTER H., NIKLAS K.J., REICH P.B., MOMMER L. Biomass allocation to leaves, stems and roots: Metaanalyses of interspecific variation and environmental control. New Phytologist. 193 (1), 30, 2011.

28. MEYER T., D'ODORICO P., OKIN G.S., SHUGART H.H., CAYLOR K.K., O'DONNELL F.C., BHATTACHAN A., DINTWE K. An analysis of structure: biomass structure relationships for characteristic species of the western Kalahari. Afr J Ecol. 52 (1), 20, 2014.

29. TIETEMA T. Biomass determination of fuelwood trees and bushes of Botswana, Southern Africa. Forest Ecol Manag. $60(3-4), 257,1993$.

30. VIDRIH M., VIDRIH T., KOTAR M. In Slovenia: Management of Intensive Land Use Systems. In: Rigueiro-Rodríguez A, McAdam J, Mosquera-Losada MR, editors. Agroforestry in Europe - Current Status and Future Prospects. Netherlands: SSBM, 397, 2009.

31. ORZEŁ S., FORGIEL M., SOCHA J., OCHAŁ W. Biomass and annual production of common alder stands of the Niepoĺomice forest. EJPAU. 8 (1), 1, 2005.

32. KEYSER T., SMITH F.W. Influence of crown biomass estimators and distribution on canopy fuel characteristics in Ponderosa Pine stands of the Black Hills. For. Sci. 56, 156, 2010.

33. KULIEŠIS A., KASPERAVIČIUS A., KULBOKAS G., KVALKAUSKIENE M. Lithuanian national forest inventory 19982002. Sampling design, methods, results. Ministry of Environment, State Forest Service. Kaunas: Naujasis lankas, Lithuania. 2003 [In Lithuanian].

34. USOLTSEV V.A., USOLTSEV A.V., KIRILLOVA V.V. Regional and species specificity of the relation between foliar biomass and dendrometric indices. Russian Forest Sciences (Lesovedenie). 32 (3), 157, 1998.

35. ZAKHAROV A.V. [3AXAPOB, A.B.] Growth and phytomass regularities of mixed oak forests in the central and Bryansk districts of the broad-leaved forest zone [Закономерности роста и фитомасса смешанных дубрав центрального и брянского округов зоны широколиственных лесов]: Dissertation of Agricultural Sciences: 06.03.02. Bryansk, 159, 2001 [In Russian].

36. TAHVANAINEN T., FORSS E. Individual tree models for the crown biomass distribution of Scots pine, Norway spruce and birch in Finland. Forest Ecol Manag. 255, 455, 2008.

37. TAPPEINER II J.C., JOHN H.H. Biomass and Nutrient Content of Hazel Undergrowth. Ecology. 54, 1342, 1973.

38. MIKŠYS V., VARNAGIRYTĖ-KABAŠINSKIENĖ I., STUPAK I., ARMOLAITIS K., KUKKOLA M., WOJCIK J. Above-ground biomass functions for Scots pine in Lithuania. Biomass Bioenergy. 31, 685, 2007. 
39. PORTÉ A., TRICHET P., BERT D., LOUSTAU D. Allometric relationships for branch and tree woody biomass of Maritime pine (Pinus pinaster Aiit.). Forest Ecol Manag. 158, 17, 2002.

40. NOGUEIRA JUNIOR L.R., ENGEL V.L., PARROTTA J.A., GALVÃO DE MELO A.C., RÉ D.S. Allometric equations for estimating tree biomass in restored mixed- species Atlantic forest stands. Biota Neotrop. 14 (2), 1, 2014

41. SUMIDA A., MIYAURA T., TORII H. Relationships of tree height and diameter at breast height revisited: analyses of stem growth using 20-year data of an even-aged Chamaecyparis obtusa stand. Tree Physiol. 33, 106, 2013. 